\title{
The pattern, sources, and growth of remittances to Pakistan: The kinked exponential approach
}

\author{
Syed Rashid Alia* \\ a PhD Student, Department of Economics, University of Karachi, Pakistan, rashidali@hotmail.com \\ * Corresponding author.
}

Received: 4 October 2019, revised: 1 November 2019, accepted: 8 January 2020, published: 8 January 2020.

\begin{abstract}
This paper examines the pattern, sources and growth of remittances to Pakistan. It analyses the growing trend of remittances and share of remittances to GDP over the period 1972-2014. We use the kinked exponential growth model (Boyce, 1986, 1987) to estimates the growing trend of remittances in Pakistan. The results show that remittances received by Pakistan have three distinct growth phases over the study period, Phase-I (1973 - 1983), Phase-II (1984 - 2000) and Phase-III (2001 - 2014). The remittances received by Pakistan have positive growth during the first and the third period while the second period shows negative growth. Before globalization, the UK was the major source of remittances to Pakistan but after globalization, the sources of remittances to Pakistan have been cantered on Saudi Arabia, the UAE, and other Gulf countries.
\end{abstract}

Keywords: Remittances, Kinked Exponential Growth Model, Economic Growth, Migration.

JEL codes: F24, O4, O1, O15.

\section{INTRODUCTION}

Remittance is the income that migrants sent back to their homes. It is proved to be a major financial instrument for many people living around the world. It is used globally to ease major or part of the financial burden by the family members left behind. Remittances are used as consumption, investment, insurance, and other financial purposes.

Remittance flows have increased globally from US $\$ 582$ to US $\$ 613$ billion from 2015 to 2017 and are expected to grow and reach US\$746 till 2020. From these amounts, the low-middle income countries received US\$ 574 billion, East Asia and Pacific received US\$ 156 billion, the South-Asia received US\$142 billion, Latin America and the Caribbean received US\$ 95 billion, Sub-Saharan Africa received US\$ 51 billion, Europe and Central Asia received US\$ 64 billion and the Middle East and North Africa received US\$ 66 billion. (Migration and Development Brief 31).

The history of remittances to Pakistan is much falcate. The amount of remittances to Pakistan was less than one percent during the 1960s. In the seventies, remittances start growing and in 1973, Pakistan received around $\$ 136$ million remittances which reached $\$ 14,900$ million in 2013. Today Pakistani Diaspora around the world comprises over 9 million with an estimated 4 million the "circulating workforce" in the Persian Gulf region. These Pakistanis have remitted around US $\$ 19.3$ billion in remittances in FY2017. Remittances to Pakistan have different sources including the UAE, US, Saudi Arabia, GCC countries (Bahrain, Kuwait, Qatar, and Oman), Australia, Canada, Japan, UK, and EU countries like Norway and Switzerland. Recently, the Government of Pakistan has started a project called "Pakistan Remittance Initiative" (PRI) to increase the amount of remittances to Pakistan.

According to the State Bank of Pakistan, more than $80 \%$ of remittances to Pakistan come from North America, the Persian Gulf, and Europe alone. From 1970 to 2003, foreign remittance proved to be the third most significant source of capital in the way of Pakistan's macroeconomic growth. But it is unfortunate that Pakistan, like other developing countries, has failed to use the inflow of remittances, and other financial flows to their own best advantage. Pakistan is unable to use these financial resources efficiently to generate a developmental momentum. Pakistan has been facing a serious scarcity of foreign exchange and remittances can fill this gap. 
Remittances can provide the much needed financial resources required by Pakistan for the structural changes in the economy. Remittances also helped in reducing the constant deficit in the Balance of Payment.

This study is a simple attempt to analyze the pattern and sources of remittances over a period of more than forty years (1973-2014). It is undeniable fact that during the early years of development, a larger inflow of remittances to Pakistan assists to minimize the problem of foreign exchange crisis and variability in the exchange rate impact on different macrocosmic variables. There may be two reasons for the immense increase in remittance payments over the years. First, during 1970, migration increased and second, the cost of sending money has declined due to technological advancement (Guiliano \& Ruiz-Arranz 2006).

If we look at the year-wise receipts of remittances to Pakistan, it is observed that there are three clear distinct phases - Phase-I, (1976 to 1983), Phase-II (1984 to 2000) and finally Phase-III (2000 onwards). Phase-I and phase-III is characterized by a steady growth of both, the absolute value of remittances and percentage share of remittances to GDP while a sharp decline in both the variables during Phase-II (Figures 1 and 2).

Pakistan is among the top ten remittances receiving country so the study of pattern and behavior of remittance is important and allow policymakers to make better policy decisions toward the utilization of remittances.

\section{LITERATURE REVIEW}

Many studies discussed the welfare and growth effects of remittances; like Ziesemer (2006), Fajnzylber, Pablo, and Humberto Lopez (2007), and Bhaskara Rao and Gazi Hassan, (2009) while numerous studies linked remittances to employment pattern (Anwar, 2004), income inequality (Oded Stark, J. Edward Taylor and, Shlomo Yitzhaki, 1986), an exchange rate (Frenkel and Mussa, 1985), schooling decision (Dietz, Gatskova, Ivlevs, 2015).

Khattak (2013) classified the remittances into two major categories: (i) Ideas and changing outlook coming into a country, (ii) Physical goods and cash. This study also observed that there is a strong and stable underlying association between foreign remittances, household consumption, savings and investment in the country.

Though the impact of the flow of remittance on Pakistan's economic growth has not been proven and some researchers have still based their arguments over whatever little data they found on the macroeconomic effects of remittance of the economy. Richard and Adams (1998) find that deficit in the current account and balance of payments reduced significantly by remittances coming from the Middle East and Europe. Iqbal and Sattar (2005) analyzed the macroeconomic importance of foreign remittance for the economy of Pakistan and argue that remittance income is considered as an injection of resources into a country's economy.

Amjad et. al., (2013) categorizes the remittance market according to official and unofficial channels and observed that Pakistan has been experiencing a favorable increase in the flow of remittances, particularly those received from official channels. This study also confirms that countries where financial systems are weak, remittance provides the best alternative to control liquidity issues.

Richard H. Adams and Jr. John Page (2005) conclude that remittances significantly strike down the level of poverty and reduce its severity. Nishat and Bilgrami (1991) employed a Keynesian structural model to analyze and make an accurate estimation of remittances multiplier. They concluded that remittances and investment, imports and consumption have a positive relationship.

On the microeconomics side, many studies link the remittances with poverty and income inequality like Khan (2014) observed that the size of the household has a direct relation with poverty and inequality. For example, a household with a large number of people living together amongst which the working adults are only a few tends to have higher poverty than households with fewer members and more at-work adults. On the other hand, Hasan (1998) and Faheem (2010) argue that those households who receive remittance regularly have an 18.4 percent marginal probability of falling below the poverty line in comparison to those who do not.

Although there is a huge literature on remittance-growth nexus, remittance's role to improve economic growth is still imprecise. Many studies found a positive association (Pradhan et al. 2008, Ziesemer 2006) while many studies found a negative association (Barajas et al. 2009, Rajan and Subramaniam 2005) between remittance and growth. So the present literature about the relationship between remittances and economic growth has contradictory findings. Pakistan is among the top ten remittances receiving country so the study of sources, pattern, and behavior of remittance is important and allows policymakers to make some better decisions toward the utilization of remittances. 


\section{METHODS}

We collected the time series data from the State Bank of Pakistan (SBP) and the World Development Indicators (WDI) and measure the percentages and point-to-point growth rates. The whole period is divided into three specific sub-periods.

For measuring the growth rates we use the simple linear exponential growth mode

$$
Q_{t}=a+b t+u_{t}
$$

The general form of the kinked exponential model for $m$ sub-periods and $m-1$ kinks $(\mathrm{k})$ is $\left(k_{1}, k_{2}, \ldots \ldots \ldots \ldots k_{m-1}\right)$. For the sub-period dummy $(\mathrm{D})$ variables $\left(D_{1}, D_{2}, \ldots \ldots \ldots \ldots D_{m}\right)$ with no continuity, restrictions are given

$$
\ln Q_{t}=a_{1} D_{1}+a_{2} D_{2}+\ldots \ldots \ldots .+a_{m} D_{m}+\left(b_{1} D_{1}+b_{2} D_{2}+\ldots \ldots \ldots . .+b_{m} D_{m}\right) t+u_{t}
$$

Where "Qt" is the growth rates in different sub-periods and "a" in the area, now employing the proper $\mathrm{m}-1$ linear restrictions,

$$
a_{i}+b_{i} k_{i}=a_{i+1}+b_{i+1} k_{i} \quad \text { for all } i=1, \ldots \ldots \ldots ., m-1
$$

The generalized kinked exponential model become

$$
\begin{aligned}
\ln Q_{t}=a_{1}+b_{1}\left(D_{1} t\right. & \left.+\sum_{j=2}^{m} D_{j} k_{1}\right)+b_{2}\left(D_{2} t-\sum_{j=2}^{m} D_{j} k_{1}+\sum_{j=3}^{m} D_{j} k_{2}\right)+\ldots \ldots \\
& +b_{i}\left(D_{i} t-\sum_{j=1}^{m} D_{j} k_{i-1}+\sum_{j=i+1}^{m} D_{j} k_{i}\right)+\ldots \ldots+b_{m}\left(D_{m} t+D_{m} k_{m-1}\right)+u_{t}
\end{aligned}
$$

where $b_{i} s$ are growth rates for different sub-periods.

The equation (4) shows the generalized kinked exponential model. This model is broken, in case of time series data, at two points (i.e. the entire time series is sub-divided into three sub-periods) is given as

$$
\ln Q_{t}=a_{1 D_{1}}+a_{2} D_{2}+a_{3} D_{3}+\left(b_{1} D_{1}+b_{2} D_{2}+b_{3} D_{3}\right) t+u_{t}
$$

This is, however, the unrestricted (discontinuous) model. The growth rates estimated from the above equation ( ) are the same as if separate exponential trends were fitted independently in each sub-period. However, when applying linear restrictions in such a way that sub-period trend lines meet at, the kinked exponential model becomes,

$$
\ln Q_{t}=a_{1}+b_{1}\left(D_{1} t+D_{2} k_{1}+D_{3} k_{1}\right)+b_{2}\left(D_{2} t-D_{2} k_{1}-D_{3} k_{1}+D_{3} k_{2}\right)+b_{3}\left(D_{3} t-D_{3} k_{2}\right)+u_{t}
$$

Coefficients, and are growth rates of three sub-periods obtained by OLS estimation.

A modified version of the kinked exponential model has been used for testing the statistical significance. The modified version is

$$
\ln Q_{t}=a_{1}+b_{1} t+b_{1}^{*}\left(D_{1} t-D_{2} k_{1}-D_{3} k_{1}+D_{3} t\right)+b_{2}^{*}\left(D_{3} t-D_{3} k_{2}\right)+u_{t}
$$

Where

$$
\begin{aligned}
& b_{1}^{*}=\text { the difference between first and second sub-period growth rates } \\
& b_{2}^{*}=\text { the difference between third and second sub-period growth rates. }
\end{aligned}
$$

This entire period is divided into three phases so, the first and second kinks occur at the 9th and 25th years of the study.

\section{ANALYSIS AND RESULTS}

The remittances to Pakistan have different sources. The percentage share of remittances coming from different sources to Pakistan is calculated and the table (1) shows that in the seventies, more than half of the country's total remittances were coming from the United Kingdom (UK) alone. Oman was the second most important country after the UK followed by the United States of America and Saudi Arabia. 
But this situation has changed in the 1980s and Saudi Arabia became the most important source of remittances. Pakistan received around 45.53 percentages of remittances from Saudi Arabia in 1980 while during the same period the percentage share of remittances declined to 8.57 percentages from the UK.

Table 1. Relative importance of Pakistan's remittances

\begin{tabular}{|c|c|c|c|c|c|c|c|c|c|c|c|c|}
\hline & & Item & FY73 & $\%$ & FY80 & $\%$ & FY91 & $\%$ & FY01 & $\%$ & FY2014 & $\%$ \\
\hline I. & & Cash Flow & 136.00 & 100.00 & $1,747.05$ & 100.00 & $1,626.92$ & 88.02 & 1021.59 & 94.019713 & 15837.68 & 99.999811 \\
\hline & 1 & USA & 9.98 & 7.34 & 61.47 & 3.52 & 190.23 & 10.29 & 134.81 & 12.406932 & 2467.65 & 15.580851 \\
\hline & 2 & U.K. & 72.13 & 53.04 & 149.72 & 8.57 & 180.05 & 9.74 & 81.39 & 7.4905436 & 2180.23 & 13.766068 \\
\hline & 3 & Saudi Arabia & 7.87 & 5.79 & 795.46 & 45.53 & 681.97 & 36.90 & 304.43 & 28.017523 & 4729.43 & 29.86183 \\
\hline & 4 & U.A.E. & 0.00 & 0.00 & 216.80 & 12.41 & 172.03 & 9.31 & 190.04 & 17.489899 & 3109.52 & 19.633647 \\
\hline & & Dubai & 0.00 & 0.00 & 86.87 & 4.97 & 68.72 & 3.72 & 129.69 & 11.935724 & 1550.03 & 9.7869578 \\
\hline & & Abu Dhabi & 0.00 & 0.00 & 105.00 & 6.01 & 75.71 & 4.10 & 48.11 & 4.4276945 & 1512.45 & 9.5496761 \\
\hline & & Sharjah & 0.00 & 0.00 & 24.93 & 1.43 & 27.60 & 1.49 & 12.21 & 1.1237196 & 45.54 & 0.2875416 \\
\hline & & Others & 0.00 & 0.00 & 0.00 & 0.00 & 0.00 & 0.00 & 0.03 & 0.002761 & 1.5 & 0.0094711 \\
\hline & 5 & Other GCC & 23.87 & 17.55 & 281.45 & 16.11 & 151.57 & 8.20 & 198.75 & 18.291504 & 1860.03 & 11.744312 \\
\hline & & Bahrain & 2.46 & 1.81 & 33.04 & 1.89 & 37.20 & 2.01 & 23.87 & 2.1968212 & 318.84 & 2.0131698 \\
\hline & & Kuwait & 7.04 & 5.18 & 111.64 & 6.39 & 15.12 & 0.82 & 123.39 & 11.355918 & 681.43 & 4.3025791 \\
\hline & & Qatar & 2.17 & 1.60 & 63.20 & 3.62 & 24.27 & 1.31 & 13.38 & 1.2313979 & 329.24 & 2.0788359 \\
\hline & & Oman & 12.20 & 8.97 & 73.57 & 4.21 & 74.98 & 4.06 & 38.11 & 3.5073672 & 530.52 & 3.3497267 \\
\hline & 6 & EU Countries & 1.80 & 1.32 & 69.60 & 3.98 & 32.62 & 1.76 & 21.5 & 1.9787036 & 431.85 & 2.72672 \\
\hline & & Germany West & 1.32 & 0.97 & 57.29 & 3.28 & 32.62 & 1.76 & 9.2 & 0.8467011 & 85.58 & 0.5403559 \\
\hline & & France & 0.00 & 0.00 & 0.00 & 0.00 & 0.00 & 0.00 & 2.22 & 0.2043127 & 34.39 & 0.21714 \\
\hline & & Netherland & 0.00 & 0.00 & 0.00 & 0.00 & 0.00 & 0.00 & 3.6 & 0.3313178 & 4.24 & 0.0267715 \\
\hline & & Spain & 0.00 & 0.00 & 0.00 & 0.00 & 0.00 & 0.00 & 0.06 & 0.005522 & 79.83 & 0.5040501 \\
\hline & & Italy & 0.00 & 0.00 & 0.00 & 0.00 & 0.00 & 0.00 & 0.55 & 0.050618 & 33.25 & 0.209942 \\
\hline & & Greece & 0.00 & 0.00 & 0.00 & 0.00 & 0.00 & 0.00 & 0 & 0 & 14.88 & 0.093953 \\
\hline & & Sweden & 0.00 & 0.00 & 0.00 & 0.00 & 0.00 & 0.00 & 0.74 & 0.0681042 & 14.89 & 0.0940161 \\
\hline & & Denmark & 0.48 & 0.35 & 12.31 & 0.70 & 0.00 & 0.00 & 3.83 & 0.3524853 & 23.7 & 0.1496428 \\
\hline & & Ireland & 0.00 & 0.00 & 0.00 & 0.00 & 0.00 & 0.00 & 0.2 & 0.0184065 & 137.6 & 0.8688125 \\
\hline & & Belgium & 0.00 & 0.00 & 0.00 & 0.00 & 0.00 & 0.00 & 1.1 & 0.101236 & 3.49 & 0.022036 \\
\hline & 7 & Norway & 0.67 & 0.49 & 14.46 & 0.83 & 21.28 & 1.15 & 5.74 & 0.5282679 & 30.77 & 0.1942831 \\
\hline & 8 & Switzerland & 0.00 & 0.00 & 0.00 & 0.00 & 0.00 & 0.00 & 4.24 & 0.3902188 & 29.42 & 0.1857592 \\
\hline & 9 & Australia & 0.00 & 0.00 & 0.00 & 0.00 & 0.00 & 0.00 & 4.15 & 0.3819358 & 159.59 & 1.0076583 \\
\hline & 10 & Canada & 2.12 & 1.56 & 7.33 & 0.42 & 11.26 & 0.61 & 4.9 & 0.4509604 & 160.03 & 1.0104365 \\
\hline & 11 & Japan & 0.00 & 0.00 & 0.00 & 0.00 & 0.00 & 0.00 & 3.93 & 0.3616886 & 7.09 & 0.0447666 \\
\hline & 12 & Others Countries & 17.56 & 12.91 & 150.76 & 8.63 & 185.91 & 10.06 & 67.71 & 6.2315359 & 672.07 & 4.2434796 \\
\hline II. & & $\begin{array}{l}\text { Sashment and Profit in } \\
\text { Pak.Rs. of Foreign } \\
\text { Exchange Bearer } \\
\text { extificates (FEBCs) \& } \\
\text { eign Currency Bearer } \\
\text { ertificates (FCBCs) }\end{array}$ & 0.00 & 0.00 & 0.00 & 0.00 & 221.37 & 11.98 & 64.98 & 5.9802866 & 0.03 & 0.0001894 \\
\hline & & Total (I+II) & 136.00 & 100.00 & $1,747.05$ & 100.00 & $1,848.29$ & 100.00 & 1086.57 & 100 & 15837.71 & 100 \\
\hline
\end{tabular}

\section{Source: Author's Calculation}

In the decade of the 1990s, the United States once again regains its position and in 1991, remittances coming from the USA have increased to 10.29 percentages. This increase continued in the subsequent decade and 
reached 15.58 percentages in 2014. The remittance percentage from UAE and Saudi Arabia reached 19.63 percentages and 19.63 percentages during 2014 respectively. It has also been observed that the relative importance of other Gulf countries has increased steadily during the subsequent periods. The importance of European Union countries as sources for remittance to Pakistan has remained the same during the same period.

The absolute value (measured at constant prices after deflating the series) of the remittances has three distinct periods as shown in figure 1. The first phase (1973 to 1983) shows the steady growth of the number of remittances. The second period (1984 to 2000) shows a falling amount of remittances and the third period $(2001-2014)$ is again observed in the recovery stage of the amount of remittance.

\section{Figurel:Amount of remittance receipts US\$ billion (at constant prices)}

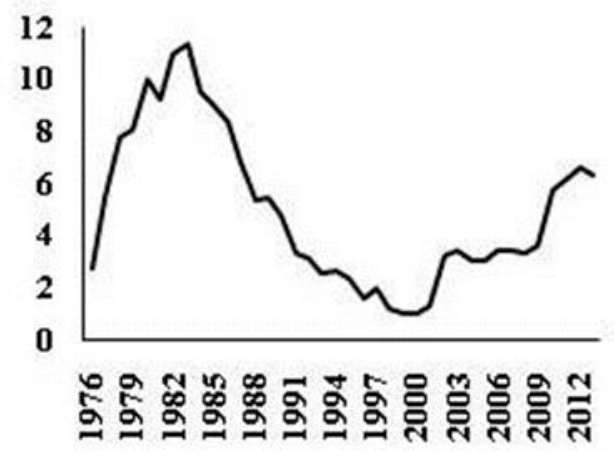

Figure 2: Share of remittances to G DP

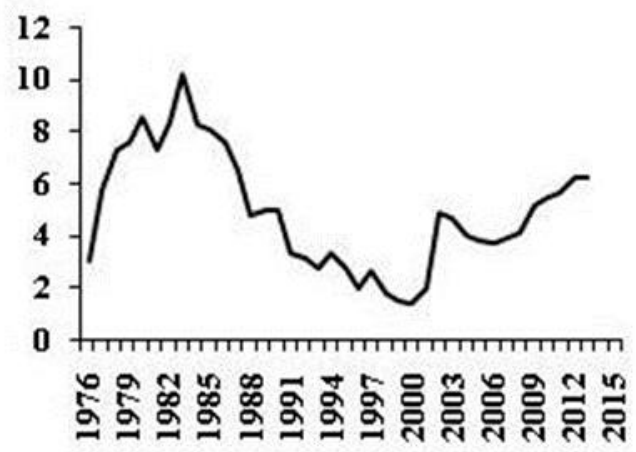

Source: World Development Indic ator, 2016

The percentage share of remittances to GDP as shown in figure 2 has a similar growth pattern as has seen in figure 1. To analyze the growths of remittances received by Pakistan from different sources and also its contribution to GDP, we have estimated the growth rates of these two variables for the three sub-periods by the kinked exponential method. The result is in table 2.

Table 2. Sub-period growth rates of remittances, and share of remittances to GDP of Pakistan (1976-2014)

\begin{tabular}{|c|c|c|c|c|c|c|c|}
\hline \multirow[t]{2}{*}{ Variable } & \multicolumn{3}{|c|}{ Kinked Exponential Growth Rate } & \multicolumn{2}{|c|}{ Trend Breaks } & \multirow[t]{2}{*}{$\mathrm{R}^{2}$} & \multirow[t]{2}{*}{ D.W. } \\
\hline & $1973-1983$ & $1984-2000$ & $2001-2014$ & $\begin{array}{l}\text { First } \\
\text { break }\end{array}$ & $\begin{array}{l}\text { Second } \\
\text { break }\end{array}$ & & \\
\hline Remittances & $\begin{array}{c}12.43^{*} \\
(3.265)\end{array}$ & $\begin{array}{l}-13.50^{*} \\
(-7.906)\end{array}$ & $\begin{array}{l}13.78^{*} \\
(6.182)\end{array}$ & $\begin{array}{c}-25.93^{*} \\
(-5.225)\end{array}$ & $\begin{array}{l}27.28^{*} \\
(7.777)\end{array}$ & 0.90 & 1.78 \\
\hline $\begin{array}{l}\text { Share of } \\
\text { remittances } \\
\text { to GDP }\end{array}$ & $\begin{array}{r}9.16^{*} \\
(2.435)\end{array}$ & $\begin{array}{r}-9.78^{*} \\
(-5.549)\end{array}$ & $\begin{array}{l}10.60^{*} \\
(4.837)\end{array}$ & $\begin{array}{r}-18.94^{*} \\
(-3.87)\end{array}$ & $\begin{array}{l}20.39^{*} \\
(5.915)\end{array}$ & 0.81 & 1.77 \\
\hline
\end{tabular}

Note: figures in the parentheses are the corresponding ' $\mathrm{t}^{\prime}$ values and ${ }^{\text {*' }}$ significant at $1 \%$.

Source: Author's Calculation

It is evident from the result that the first and third sub-periods witnessed a positive growth phase both in terms of total remittances received and the share of remittances to GDP. More specifically, during the first sub-period, the total remittances and its share to GDP witnessed annual growth rates of 12.43 and 9.16 percent respectively. However, the total remittances and its share to GDP became negative during the second subperiod. After the globalization policy being implemented, the growth rates during 2001 and thereafter have regained their position strongly. So the respective growth rates achieved during the third sub-period were 13.78 and 10.76 percent per annum. It is also evident from the results that the difference between the decadal growth rates (which is technically called trend breaks) is also statistically significant. Thus, the policy of globalization happens to be fruitful for Pakistan in case of remittances. 


\section{CONCLUSIONS}

This study analyses the growing trend of remittances and share of remittances to GDP over the period 1972 2014 by using the kinked exponential model (Boyce, 1986, 1987). The results confirm that remittances received by Pakistan have three distinct phases. The first phase is from 1973 to 1983, the second phase is from 1984 to 2000 and the third phase is from 2001 to 2014. The remittances received by Pakistan have positive growth during the first and the third phase while the second phase shows negative growth. Further, before globalization, the UK was the major source of remittances but after globalization, the sources of remittances to Pakistan have been centered on Saudi Arabia, UAE, and other Gulf countries.

\section{REFERENCES}

Amjad, R., Irfan, M. and Arif, G.M. (2013). How to increase formal inflows of remittances: an analysis of the remittance market in Pakistan. International Growth Center, WP, 2013.

Anwar T. (2004). Recent macroeconomic developments and implications for poverty and employment in Pakistan. Australia South Asia Research Centre, Working Paper 2004-14. https://link.springer.com/chapter/10.1057/9780230520318_5

B.Bhaskara Rao and Gazi Hassan. (2009). A panel data analysis of the growth effects of remittances. Economic Modelling, 28, 1-2, January-March 2011, 701-709

Barajas, A., R. Chami, C. Fullenkamp, M. Gapen, P. Montiel. (2009). Do workers' remittances promote economic growth? International Monetary Fund Working Paper No. WP/09/153. Washington DC. IMF.

Boyce, J. K. (1986). Kinked exponential models for growth-rate estimation. Oxford Bulletin of economics and statistics, 46.

Boyce, J. K. (1987). Agrarian Impasse in Bengal: Institutional Constraints to Technological Change. Oxford University Press, New York.

Dietz, Gatskova, Ivlevs. (2015). Emigration, remittances and the education of children staying behind: Evidence from Tajikistan. Iza Institute for the Study of Labor. IZA Discussion Paper No. 9515.

Faheem, K. (2010). Issues in Pakistan's Economy. Peshawar.

Fajnzylber, Pablo, and Humberto Lopez. (2007). Close to home: The development impact of remittances in Latin America. Washington, DC: World Bank.

Frenkel, J. and M. Mussa. (1985). Asset Markets, Exchange Rates, and the Balance of Payments. Handbook of International Economics 2, 14.

Giuliano, P., \& Ruiz-Arranz, M. (2006), Remittances, Financial Development, and Growth. Discussion Paper No. 2160, Institute for the Study of Labor IZA, International Monetary Fund, Working Paper No. 05/234

Hasan, P. (1998). Pakistan's economy at the crossroads: past policies and present imperatives. Oxford University Press.

Iqbal Z. and Sattar A. (2005). The contribution of worker's remittances to economic growth in Pakistan. Pakistan Institute of Development. Research report, 187.

Khattak. Z. (2013). Econometric analysis of income, consumption, and remittances in Pakistan: two-stage least square method. Journal of Commerce.5, 4.1-10.

Khan A. (2014). Economics of Pakistan. 9th edition. (Pakistan). Migration and Development Brief 29, April 2018, the World Bank

Nishat, M. and Bilgrami, N. (1991). The impact of migrant worker's remittances on Pakistan's economy. Pakistan Economic and Social Review. 29.1.

Oded Stark, J. Edward Taylor, and Shlomo Yitzhaki. (1986). Remittances and Inequality. The Economic Journal. 96, 383. $722-740$

Pradhan, G., Upadhyay, M. \& Upadhyaya, K. (2008). Remittances and economic growth in developing countries. The European Journal of Development Research. 20(03). 497-506.

Raghuram G. Rajan \& Arvind Subramanian. (2008). Aid and growth: what does the cross-country evidence really show? The Review of Economics and Statistics. 90(4), 643-665, 06.

Richard H. Adams and Jr. John Page. (2005). Do international migration and remittances reduce poverty in developing countries? World Development.33.10, 1645-1669

Richard H. and Adams. Jr. (1998). Remittances, Investment and Rural Asset Accumulation in Pakistan. Chicago Journals. The University of Chicago Press

State Bank of Pakistan. (2014), Country-wise workers' remittances.

World Bank. (2019). Migration and Development Brief 31.

Ziesemer, T. (2006). Worker Remittances and growth: the physical and human capital channel. unu-merit working paper series, 020, United Nations University. 